
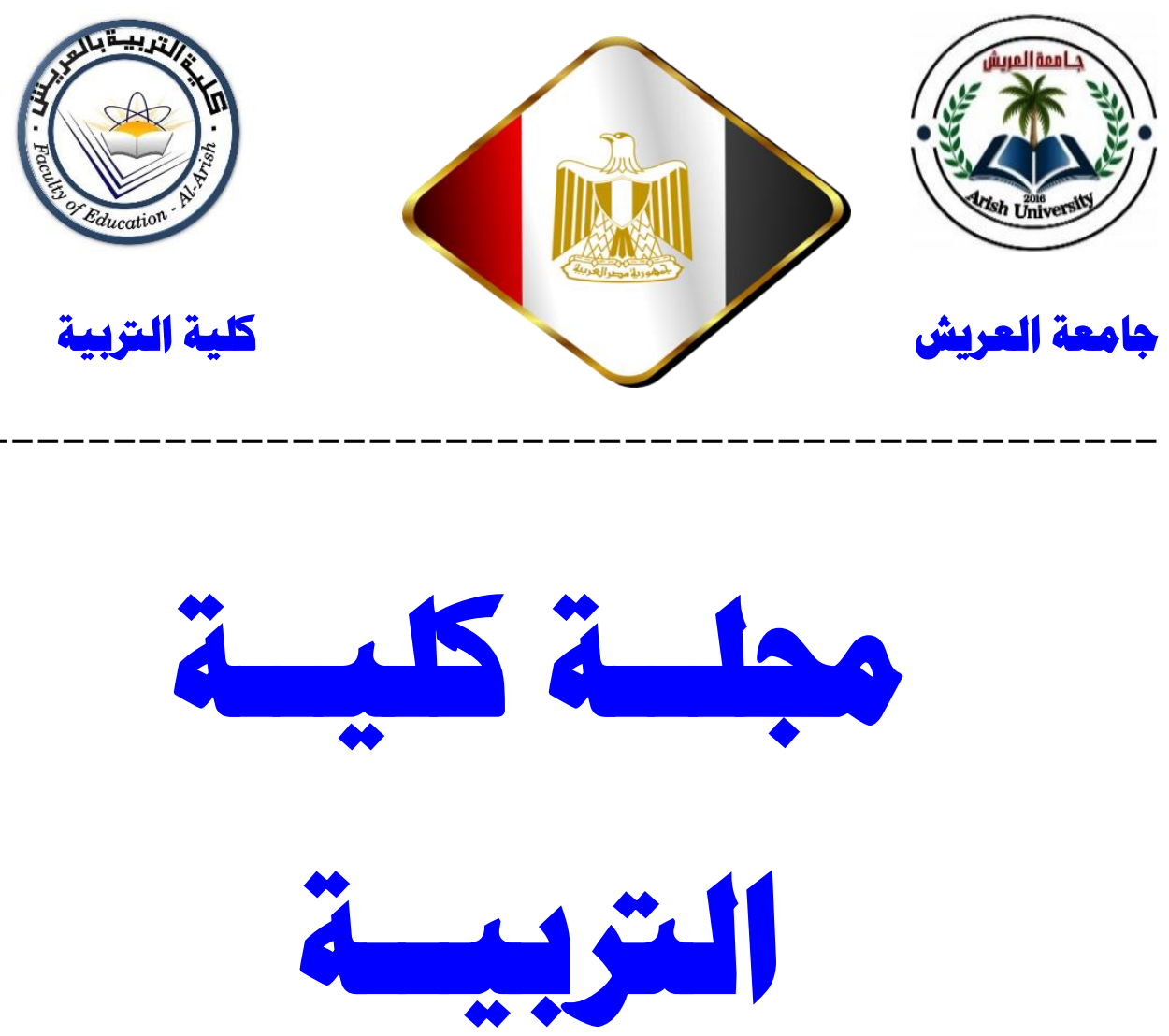

علمية محكمة ربع سنوية

(السنة السادسة - العدد السادس عشر -أكتوبر ^| •؟م)

j_foea@aru.edu.eg 
الإشراف الع

\begin{tabular}{|c|c|}
\hline (رئيس مجلـد الكلية & أ.د. رفعت عمر عزوز \\
\hline وكيل الكلية للاراسات العليا والبحوث & أ.د. السيد كامل الشريينح \\
\hline
\end{tabular}

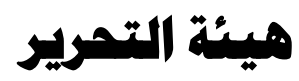

\begin{tabular}{|c|c|}
\hline رئيس التحرير & أ.د. محمد رجب فضل الله \\
\hline مدير التحرير & أ.د. أحمد عبد العظيم سالم \\
\hline عضو & د. كمال طاهر موسى \\
\hline عضو & د. أسماء حسن صبًاح \\
\hline
\end{tabular}

\section{الإشراف المالي والإداري}

\begin{tabular}{|l|l|}
\hline أ. محمد إبراهيم محمد عربيي أسماء محمد علي الثاعر المسؤول المالي \\
\hline أمسؤول الإداري
\end{tabular}




\section{قواعد النشر بمجة كلية التربية بالعريش}

ا. تتشر المجلة البحوث والدراسات التي تتوافر فيها الأصالة والمنهجية السليمة على ألا يكون

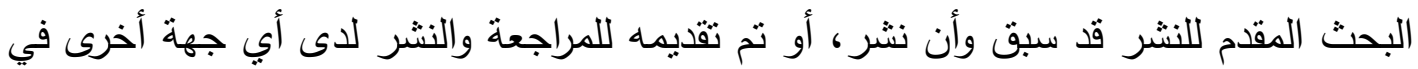
نفس وقت تقديمه للمجلة.

r. تُقبل الأبحاث المقدمة للنشر بإحدى اللغتين: العربية أو الإنجليزية.

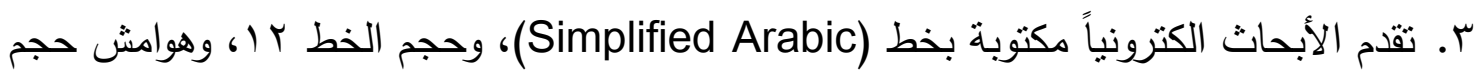
الواحد منها ه.r.بم، مع مراعاة أن تتسق الفقرة بالتساوي ما بين الهامش الأيسر والأيمن وهن (Justify) . وترسل إلكترونياً على شكل ملف (Microsoft Word). ء. يجب ألا يزيد عدد صفحات البحث المُحكم بما في ذلك الأشكال والرسوم والمراجع والجداول والملاحق عن (ro) صفحة. (الزيادة بحد أقصى ، (1 صفحات برسوم إضافية). ولا يزيد البحث المُستل عن ( • r صفحة ) (الزيادة بحد أقصى م صفحات برسوم إضافية). ه. يقدم الباحث ملخصاً لبحثه في صفحة واحدة، تتضمن الفقرة الأولى ملخصاً باللغة العربية، والفقرة الثانية ملخصاً باللغة الإنجليزية، وبما لا يزيد عن .. ب كلمة لكل منها. 7 . يكتب عنوان البحث واسم المؤلف والمؤسسة التي يعمل بها على صفحة منفصلة ثم يكتب عنوان البحث مرة أخرى على الصفحة الأولى من البحث. V. يجب عدم استخدام اسم الباحث في متن البحث أو قائمة المراجع ويتم استبدال الاسم بكلمة

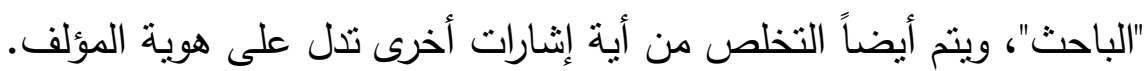

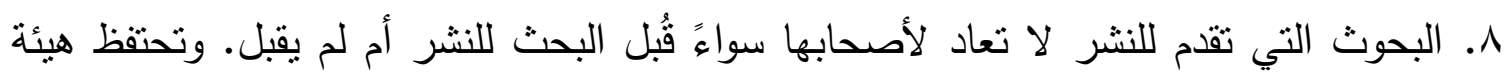
التحرير بحقها في تحديد أولويات نشر البحوث. 9 . لن ينظر في البحوث التي لا تتفق مع شروط النشر في المجلة، أو تلك التي لا تشمل على ملخص البحث في أي من اللغتين، أو يزيد عدد صفحاتها عن هب صفحة شاملة الصفحات

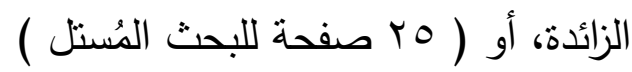
• . . يقوم كل باحث بنسخ وتوقيع وإرفاق إقرار المواققة على اتفاقية النشر . 
11 ( بسهم الباحث في تكاليف نشر بحثه، ويتم تحويل التكلفة على الحساب الخاص بالمجلة. يجب إرسال صورة عن قسيمة التحويل أو دفع المبلغ، مع البحث الكترونيا. التكاليف تشمل: مكافأة

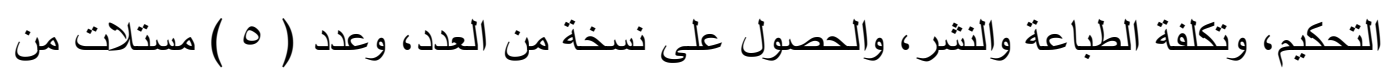

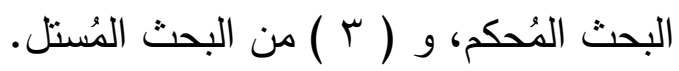
ب ا. يتم نشر البحوث أو رفض نشرها في المجلة بناءً على تقاربر المحكمين، ولا يسترد المبلغ في حالة رفض نشر البحث من قبل المحكمين. سا. يُمنح كل باحث إفادة بقبول بحثه للنشر بعد إتمام كافة التصويبات والتعديلات المطلوبة، وسداد الرسوم المقرة.

\section{قواعد التمكيم بمبلة كلية التثبهية بالمريشي}

فيما يلي القواعد الأساسية لتحكيم البحوث المقدمة للنشر بمجلة كلية التربية بالعريش

\section{القواعد عامهة:}

1. ـ مدى ارتباط موضوع البحث بمجال التربية. r. مدى مناسبة الدراسات السابقة، وإبرازها لرؤى متعددة.

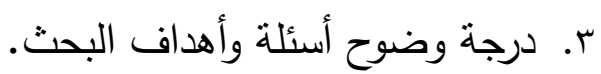

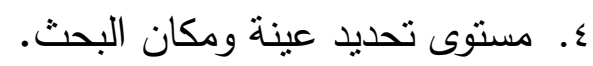
ه. درجة إتباع البحث لمعايير التوثيق المحددة في دليل رابطة علم النفس الأمريكية، العدد السادس.

ا. احتواء قائمة المراجع على جميع الدراسات المذكورة في منن البحث والعكس أيضاً صحيح.

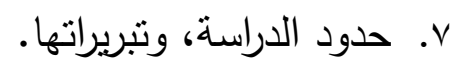
^. سلامة تقرير البحث من الأخطاء اللغوية المتعلقة بالنحو والإملاء وكذا المعنى. 9. تكامل جميع أجزاء تقرير البحث، وترابطها بشكل منطقي.

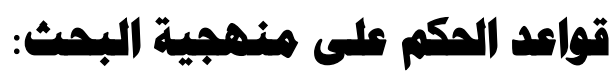
ا. تحديد الفترة الزمنية للبحث. 
r. تحديد منهجية مناسبة للبحث. r. تبرير إجراءات للاختيار في حالة دراسة الأفراد أو الجماعات. ء. تضمين البحث إطاراً نظرياً واضحاً. ه. توضيح الإجراءات المتعلقة بالجوانب المهنية الأخلاقية منل: الحصول على موافقة

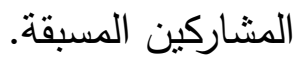

\section{قواعد تمكيم الإبمراكات:}

1. شرح وسائل جمع المعلومات بوضوح، والعمليات المتبعة فيها. r. تحديد وشرح المتغيرات المختلفة.

r. نترقيم جميع الجداول والأشكال والصور والرسوم البيانية بشكل مناسب وتبوييها والتأكد من سلامتها. ع. شرح عملية التحليل المتبعة ومبرراتها، والتأكد من اكتمالها وسلامتها. قواعد الهكم على النتاجه:

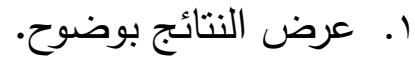

r. توضيح جوانب الاختلاف في حالة تعارض نتائج البحث مع نتائج الدراسات السابقة. r. اتساق الخاتمة والتوصيات مع نتائج البحث. 


\section{همتويات العدد ( 17 )}

\begin{tabular}{|c|c|c|c|}
\hline \multicolumn{2}{|c|}{ هيئة التحرير } & \multicolumn{2}{|l|}{ قيادة ودماء بحديدة ثابتة... قيم } \\
\hline الصفمات & الباحث & عنمان البمث & الرقم - الرق \\
\hline \multicolumn{4}{|c|}{ 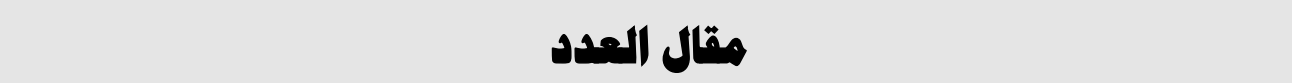 } \\
\hline $13-46$ & 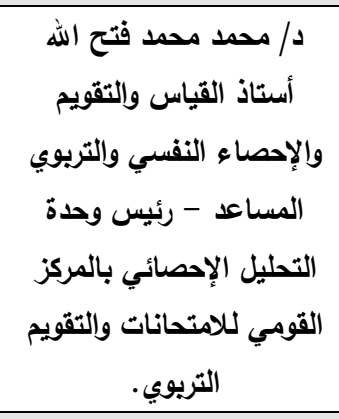 & بنوك الأسئلة والتصحيح الإلكتروني: & \\
\hline \multicolumn{4}{|c|}{ بموث ودراسات مصكمة } \\
\hline 49-96 & 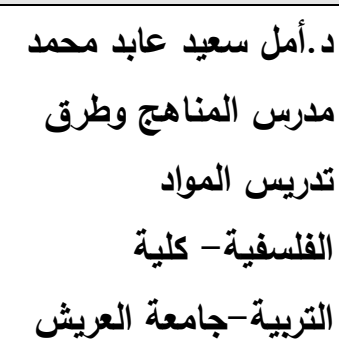 & 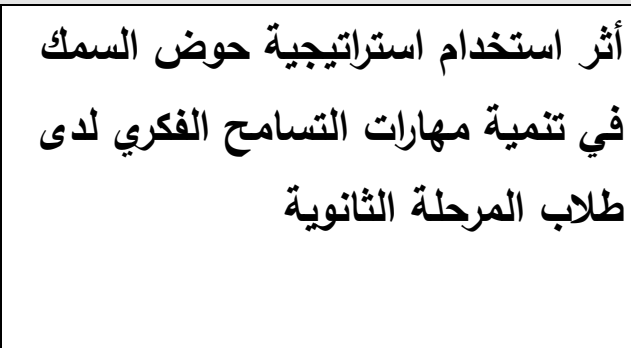 & 1 \\
\hline $97-134$ & $\begin{array}{l}\text { Dr. Mahdi M. A. } \\
\text { Ibrahim } \\
\text { Assistant Professor } \\
\text { ،of TEFL } \\
\text { Dept. of Curriculum } \\
\text { \& Instruction } \\
\text { Faculty of } \\
\text { Education, Arish } \\
\text { University }\end{array}$ & $\begin{array}{l}\text { The Effectiveness of Using } \\
\text { the SCAMPER Model in } \\
\text { Enhancing EFL Learners' } \\
\text { Essay Writing Skills and } \\
\text { their Attitudes towards it }\end{array}$ & r \\
\hline $\begin{array}{c}135- \\
185\end{array}$ & محمد دينا محمد أحمد & الفروق في جودة الحياة لاى الطلاب & $r$ \\
\hline
\end{tabular}




\begin{tabular}{|c|c|c|c|}
\hline & كلية التربية التربية الخاصة -جامعة & بعض المتغيرات & \\
\hline \multicolumn{4}{|c|}{ 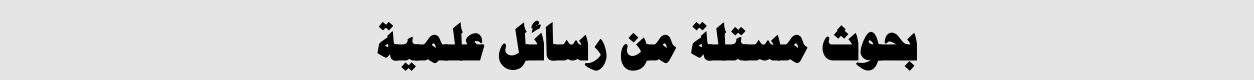 } \\
\hline $\begin{array}{l}189- \\
222\end{array}$ & 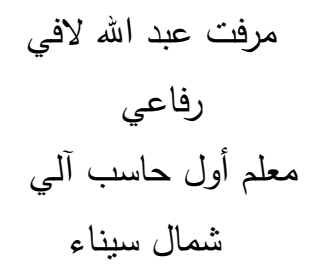 & 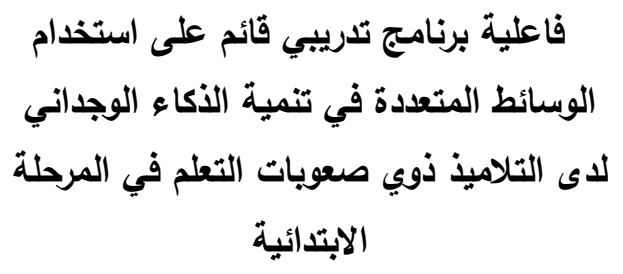 & 1 \\
\hline $\begin{array}{l}223- \\
257\end{array}$ & 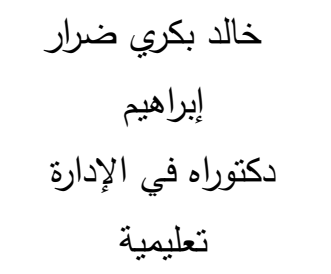 & 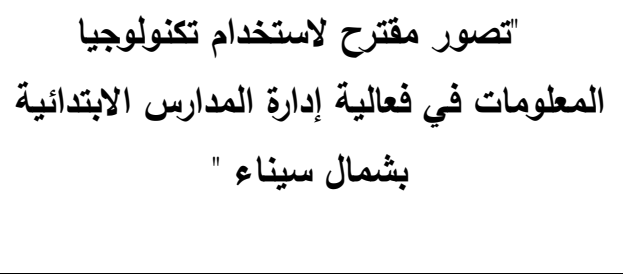 & $r$ \\
\hline $\begin{array}{c}259- \\
292\end{array}$ & 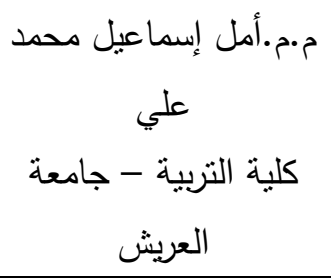 & فاعلية برنامج قائم على الدعامات التعليمية & $r$ \\
\hline
\end{tabular}




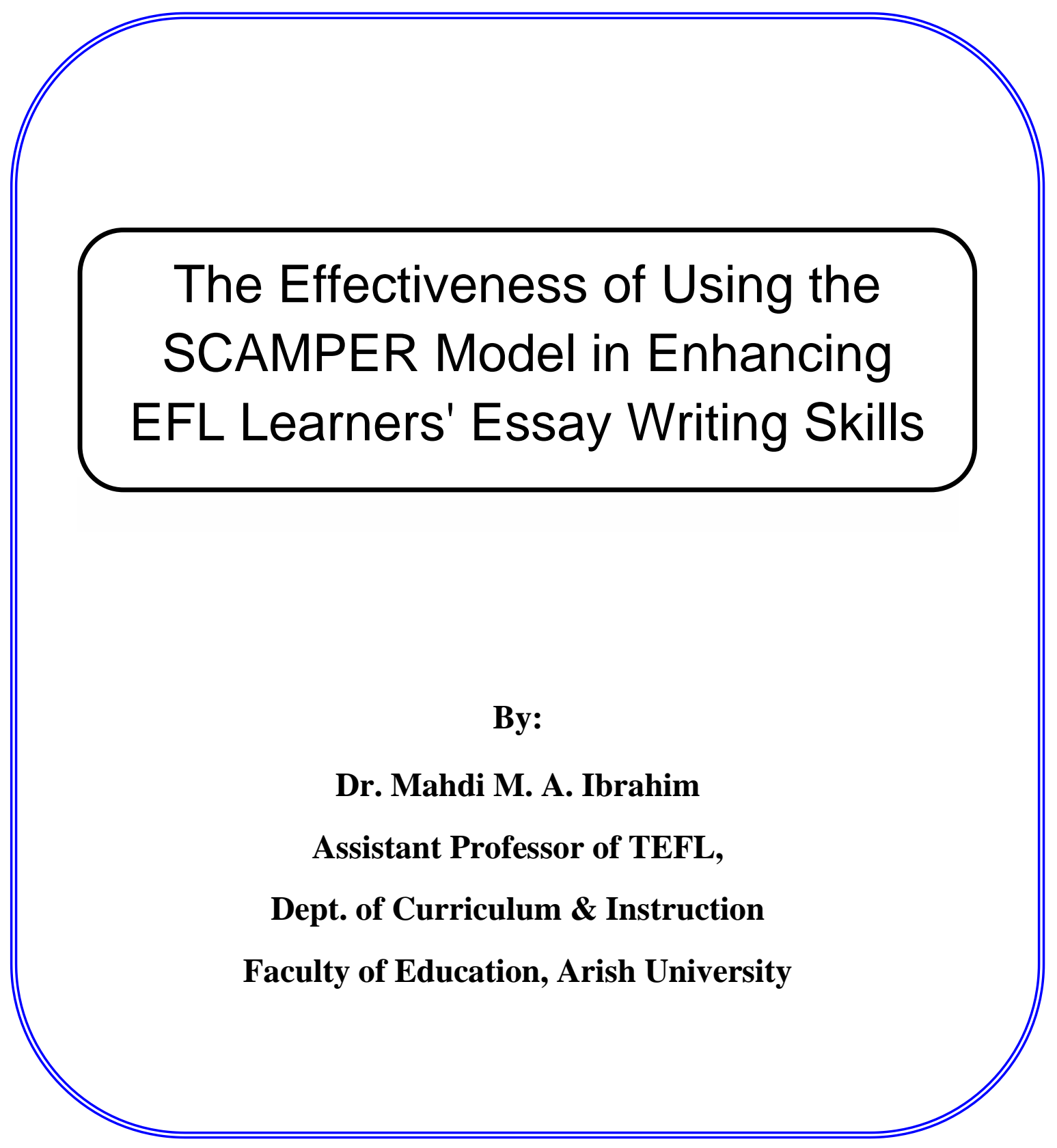




\title{
The Effectiveness of Using the SCAMPER Model in Enhancing EFL Learners' Essay Writing Skills and their Attitudes towards it
}

\author{
By: \\ Dr. Mahdi M. A. Ibrahim \\ Assistant Professor of TEFL, \\ Dept. of Curriculum \& Instruction \\ Faculty of Education, Arish University
}

\section{Abstract:}

This experimental study examined the effectiveness of using the SCAMPER Model in developing the essay writing skills of EFL learners and their attitudes towards using it. The study sample consisted of 64 students enrolled in the English Department, Faculty of Education, Arish University during the first semester of the school year 2018-2019. The ages of the participants ranged from $21-22$ years old. The training of students on the use of SCAMPER Model on developing their essay writing skills took 28 hours. The participants were pre and post tested. The instruments used in the study included an essay writing scoring rubric and a 24-item attitude measurement. Statistical analysis was used via two statistical programs namely; the SPSS program and Haridy's statistical analysis program H-EESC for the effectiveness and effect size in the educational programs and researches. The study found that the SCAMPER Model has had a large effect upon developing all EFL learners' essay writing skills namely; ideas, organization, word choice, structure, 
mechanics of writing and editing. Findings also indicate that the respondents' answers to the measurement items show their positive attitudes towards the use of the SCAMPER Model on developing their essay writing skills.

Keywords: SCAMPER Model, Essay Writing Skills, EFL, Attitudes.

\section{Introduction and Background}

Explicitly speaking, academic achievement and memorization of the subject matter are no longer the only ultimate goals of any successful educational system. To overcome today's challenges, obstacles and consequences, EFL students need to be equipped with high-level academic skills that maximize their academic potential, develop their creative and critical thinking skills, effective skills for working alone, in pairs and in groups. Therefore, various procedures, techniques, methods, and strategies need to be suitably utilized to hone EFL learners' skills to be successfully involved in various academic tasks and activities.

Writing has been a part and parcel of EFL students' learning process. During their period of study, university EFL students endeavor a range of various meaningful writing tasks such as essays, reports, book/article reviews, literature review, etc.

It has become crucial for EFL students that in order to achieve the best of academic and social life they develop their writing skills as the social media has now taken communication to a whole new level. In their classroom writing activities, students often express their own ideas, expressions and experiences to develop an essay around a certain topic provided to them by their teachers. In this respect, Muschla, (2011) assures that the "students must learn how to compose sentences, build paragraphs, and express ideas within the standard of written 
English.”(p. xv) According to Doly, (2013) effective writing is characterized by some attributes such as being purposeful, reader centered, clear, concise, accurate, complete, objective and correct.

Moreover, in her online blog, Donovan, (2017) stated some of characteristics of good writing such as the clarity and focus, organization, ideas and themes, word choice, mechanics of writing; spelling, capitalization, grammar and style and though provoking or emotionally inspiring. However, students need help to be more strategic when they work on written tasks. When writing, students' imaginations need to be sparked and ignited in order to generate, develop and produce in hand topic related ideas. In addition, students need to be taught how to go through the writing processes of planning, drafting, writing, revising, and editing.

Writing is crucial for all students at all educational levels to enhance their thinking and communication skills (Coffin et al., 2003). It is not an easy job. It is a complex intellectual process that requires the ability to use the skills and conventions in order to convert a hidden thought into a clear, effective, written text to be smoothly understood by others. Moreover, Egyptian university students "mostly write for summative assessment purposes in the form of course tests" (Ahmed, 2011, p. 56). According to Irvin (2010), when students develop their essay writing, they are supposed to navigate through a new terrain of information so they must develop ways for grasping new subject matter in order to use in their writing.

In order to write a good essay, EFL students need to hone their essay writing skills such as the proper use of good ideas, organization, word choice, structure, mechanics of writing and editing. Besides, they need a motivating strategy to help them generate ideas, use cooperative work, enhance creativity, find innovative ideas, develop talents, motivate their flexibility, fluency and originality. 


\section{Review of Literature}

The four Language skills of listening, speaking, reading and writing have been a subject of importance for most researchers during the last two decades. Writing is a pure thinking skill that has been the focus of most thinking strategies such as cooperative writing, the six thinking hats strategy, and SCAMPER Model.

According to (Besant, 2016; Mulder,2018), the SCAMPER model was developed by Bob Eberle in 1971. In his book "Games for Imagination Development" using the checklist created by Alex Faickney Osborn, founder of the Alex Osborn Brainstorming Technique which aimed at enabling a group of people to come up with a suitable solution for a certain problem by generating a big number of interrelated ideas without being criticized by any of the group members.

This model, however, is used to develop learners' thinking skills, creativity, imagination and motivation. Each of the seven letters of SCAMPER indicates a specific technique for generating innovative ideas and solutions for existing problems. The letters are "an acronym for a set of operations or categories: (S) Substitute, (C) Combine, (A) Adapt, (M) Modify/Magnify/ Minimize, (P) Put to another use, (E) Eliminate and (R) Reverse/ Rearrange." (Idek, 2016, 31-53)

In Egypt, essay is one of the courses of study offered to EFL learners at the Faculty of Education at the university level. According to Loveless, (2018), the basic format for an essay usually consists of five paragraphs and it might be more. It usually consists of the three parts namely; an introduction, a body and a conclusion. Writing an essay can be a challenging task for the majority of EFL learners because the essay writer has to follow certain steps that ensure what is being written is accepted and appreciated by others. Some research studies have paid attention to the reasons as to why EFL students find it difficult to 
write. Such reasons include the lack of information EFL students have about the subject they write about and the lack of feedback from their teachers.(Chang,2012). Other studies relate this difficulty to the limited focus of the feedback provided on students' writing and that the focus of feedback is limited to some of the mechanics of writing such as spelling and the use of grammatical rules, Ahmed (2010).

Besides, it has been reported that it is difficult for some teachers to help their students to produce a well written piece of writing (Okasha \& Hamdi, 2014; Al-Jarrah et al., 2018). In addition, what makes writing a challenging process is that "it needs much effort and skill, especially when it is done in a foreign or second language." (Abdakkah, 2015: 10). Abu-Seif and Magableh (2016: 289), state that "essay writing requires the ability to produce a clear written text in terms of its ideas, style, and converting one's thoughts to a written text that clearly reflects the ideas and feelings of the writer." These activities can be achieved in one prime essay writing skills namely; brainstorming. In brainstorming, as Ryan, (2017) pinpoints, ideas are generated, outlined and given the suitable structure. The aim of brainstorming according to Abdallah, (2015) is to make the writing process clear and manageable to help students improve the quality of their written work. According to Horn, (2016), brainstorming encourages students to think of new ideas, combine existing ideas in new ways, and generate original and often unusual ideas.

Regarding developing and investigating the academic essay writing skills, the focus of some studies was on three main processes namely; organization, idea generation and point elaboration (Zaiyadi, Abdullah \& Muhamad, 2015). Other studies focused on brainstorming as a main process for generating ideas. In this respect, Davis, (2015) suggests two techniques for brainstorming namely; Fill the Page and Stay Organized. In the Fill the Page technique, the writer starts to write key words and sentences that come to their mind around the target topic. This technique helps to quickly gather one's thoughts without any 
pressure of creating an actual draft. In The Stay Organized technique, a diagram can be used to quickly gather thoughts on the target topic in an organized way.

In spite of the limited number of previous studies on the impact of SCAMPER on the development of academic essay writing skills, some of these studies have indicated that the well use of this model leads to the enhancement of students' cognitive development, motivation, creativity, (Torman \& Altun, 2013; Ozyaprak, 2016). In addition, the promising impact of the SCAMPER Model on creativity as reported by Ablahad and Fataah (2003) as cited in Khawaldeh \& and Ali (2016: p. 8), "showed differences of statistical significance on the total score of creativity and its sub-dimensions i.e. flexibility, originality and fluency."

The term "SCAMPER" however, is viewed differently by various researchers, and educators. For example, it is viewed as a program by Khawaldeh and Ali (2016), Al Harthy (2015), Al Badarin (2006), Ablabad and Fataah (2003). In addition, it is viewed as strategy by Abu-seif and Magableh (2016), Alrowethy (2012). Besides, it is viewed as a method by Colby, (2014). It is viewed as a model by Buser, Gladding and Wilkerson (2011). It is seen as a technique by Harman and Attun (2013), Yagci (2012),Çelikler and Harmer (2015) andIdek (2016), Ozyaprak (2016). It is thought of as a tool by Magid, Tan and Soh, (2003). However, the most important thing in this respect is how SCAMPER is looked at. For example, it can be viewed as a strategy if it is used as a strategy, a model if it is used as a model, a technique if it is used as a technique and so on.

The SCAMPER model is extremely popular nowadays. It is used in all aspects, levels and specializations of education. It was first introduced by Eberle for generating ideas that help solve problems, targeted questions, brain storming meetings and sessions. Later on, it was introduced to educational contexts to help learner's think creatively. This model helps students think differently about an existing subject. 
In educational settings, in has been found out that the SCAMPER model has a tremendous number of positive effects. For example, it is used to entertain learners, apply ideas, enhance creativity, solve problems, find innovative ideas, meet different learning capabilities \& development, develop talents, develop students' flexibility, fluency and originality and motivate learners' self-concept \& creative skill acquisition, ( El-Zraigat, 2012; Yagci, 2012; Chulvi, González -Cruz, Mulet \& AguilarZambrano, 2013; Harman \& Celikler, 2015; Ozyaprak, 2016 ). Similarly, Serrat, (2009) asserts that the SCAMPER Model motivates learners, helps them produce original ideas and is a successful brainstorming technique.

Nowadays, there is a rapid growing research studies on the use of the SCAMPER Model in various educational settings. For example, Richards and Lassonde, (2011) have spotlighted the significance of the SCAMPER model in writing. They indicated that SCAMPER model is flexible and can be adapted in writing for a couple of reasons, such as to meet the needs of students in terms of writing and to move the writing development progressively forward.

Moreover, in a pilot study of a three-hour SCAMPER workshop on secondary students, conducted by Poon, Au, and Sing Lou (2014), the 74-student sample expressed their satisfaction with the workshop and enjoyment of creativityenhancing workshop components. Likewise, in their study that aimed at understanding the influence of the SCAMPER Model in ideation metrics such as quantity, fixation and novelty when working with instructional design problems, Moreno et al., (2014) concluded that the SCAMPER Model has a very strong impact on brainstorming, developing generating ideas and creativity.

Abdul-Qader and Ismail, (2015) reported the effectiveness of SCAMPER-based teaching for developing the creative writing of their students. Other positive effects have been reported on getting more self-confidence and appreciation of the subject matter as a result of using SCAMPER strategy in 
the understanding of historical events (Nagmueddin, 2014), developing creative writing of primary school pupils (AlHussaini, 2013) enhancing generating ideas in essay writing of university students (Al-Thanyan, 2015). SCAMPER, according to Horn, (2016), is designed to encourage learners to generate unique thoughts, explore relationships, and search for new or different combinations.

The results of Al- Harthy's quasi-experimental study (2015) showed that the students of the experimental group who studied vocabulary according to the SCAMPER Model outperformed their counterparts of the control group who studied vocabulary using the traditional method.

Abu-saif and Magableh's study (2016) that aimed at investigating the effect of using SCAMPER's strategy for developing the creative writing skills of the $10^{\text {th }}$ grade female students in Jordan, found out that the experimental group that was taught by the SCAMPER's strategy was superior to the control group in terms of developing the creative writing skills. Besides, Islim \& Karatas's study (2016) investigated the effect of SCAMPER on the creative problem solving skills and academic achievements of 40 high school students. Participants were assigned to an experimental groups and a control one. Both groups were pre and post tested. Results indicated that SCAMPER is a fun and a good brainstorming teaching method that had a positive effect on students' creativity and academic knowledge. In addition, Fahmy, Qoura and Hassan (2017) examined the effectiveness of using the SCAMPER Model in teaching "story" to enhance the speaking skills of EFL primary school learners. The study sample included 60 participants divided into two groups; experimental and control groups. Participants were pre and post tested. Results revealed the effectiveness of using SCAMPER Model in teaching story to enhance EFL learners' speaking skills.

In addition, Sawalha \& Abu Jarad's study (2017) tended to develop the Jordanian ninth grade students' creative writing via a SCAMPER program. The results show that the program had 
positive results upon the improvement of students' creative writing. Moreover, the results of Şenel'srecent study (2018) indicated that the use of SCAMPER Model had a positive effect on the development of the participants' creative writing skills.

Significantly, EFL students in the Egyptian universities usually sit for the final written examinations and are evaluated according the quality of their writings. To produce a flawless written work, students need to show good ideas, organize their writing, cleverly choose their words and expressions and correctly use structures and mechanics of writing (i.e. grammar, spelling, punctuations) and convert their thoughts into a written format that is understood, appreciated and acknowledged by their professors. In addition, the majority of university students' tests and assignments are evaluated in their written format. Egyptian students as Ahmed, (2011) pinpoints "perceive EFL essay writing as a difficult skill that they have not mastered which justify their low scores in the essay writing exam, p. 56." Moreover, writing according to Şene, (2018) "is regarded as the most challenging task and the most difficult language skill among EFL students." The inability to produce well written essays is an issue that is recently shown in a pilot study conducted by the researcher when he asked third year students to write two paragraphs about the course of Methods of Teaching. One paragraph about what they liked about the course and another paragraph about what they did not like about it. The majority of the students wrote poorly written sentences and this shows that the students are in a critical need to hone their own essay writing skills using a motivating method that helps them find innovative ideas and solutions. The SCAMPER model was used for enhancing the EFL university student's skills to expand their essay writing skills accordingly.

\section{The Context of the Problem}

Enhancing EFL learners' essay writing skills has been ignored at the university level. There is a greater emphasis on correcting mistakes than providing students with strategies for improvement (Al-Roomy, 2016). A number of studies (e.g., Muslim, 2014; 
Muhammad, 2015; Al-Roomy, 2016) note that although students might know different writing strategies, they often seem to be unable to implement them and that students complain of making writing mistakes even at the sentence level. Furthermore, most teachers of writing struggle over which appropriate strategy is most effective to fulfill the writing course objective (Abdessamad, 2016). However, there are problems in students' writing skills such as generating ideas, word choice, mixing a number of ideas in one paragraph, and lack of coherence. Besides, EFL students are expected to write well, but are not taught to do so (Koura \& Zahran, 2017, p.184).

\section{Statement of the Problem}

In the light of the literature review and the results of the pilot study, it was observed that EFL learners encounter many writing challenges that might be attributed to various reasons such as using traditional strategies, lack of vocabulary, word choice, spelling and low educational outcomes. Therefore, the researcher suggests using the SCAMPER Model as an alternative strategy for developing EFL learners' essay wring skills.

\section{Questions of the Study}

The problem of the study can be stated in the following questions:

1. What is the proposed SCAMPER based-program for developing EFL learners' essay writing skills?

2. What is the effectiveness of the SCAMPER model in enhancing the EFL learners' essay writing skills?

3. What is the effectiveness of using the SCAMPER Model in EFL learners' attitudes towards using this model for enhancing their essay writing skills?

\section{Significance of the Study}

The study gains its significance from the following: 
1. Providing a new prospective in TEFL through the use of the SCAMPER Model in developing the EFL students' essay writing skills and their attitude towards SCAMPER Model

2. Paving the way for similar studies to investigate the use of SCAMPER model in other areas of teaching English as a foreign language.

\section{Purpose of the Study}

The study aimed at:

1. Developing a training program based on the SCAMPER Model activities for enhancing EFL learners' essay writing skills.

2. Utilizing the proposed training program to enhance EFL learners' essay writing skills.

3. Exploring the effects of using the SCAMPER Model on enhancing EFL learners' essay writing skills.

4. Investigating EFL learners' attitudes towards using the SCAMPER Model in enhancing their essay writing skills.

\section{Hypotheses of the Study}

1. There are statistically significant differences at the 0.05 level between the pretesting and post testing of the experimental group in terms of enhancing essay writing skills of EFL learners in favor of the post testing.

2. There are statistically significant differences at the 0.05 level between the pre administration and post administration of the experimental group in terms of enhancing essay writing skills of EFL learners in favor of the post administration.

\section{Delimitations of the Study}

This study was delimited to:

1. The third year students, English Department, Faculty of Education, Arish University. 
2. The SCAMPER model as a teaching strategy.

3. The essay writing skills namely; ideas, organization, word choice, structure, mechanics of writing and editing.

\section{Definition of Terms}

\section{SCAMPER}

SCAMPER was originally suggested as a tool by Alex Osborn (1953) in his book Applied Imagination, but the tool itself was made real by Bob Eberle in his 1971 book SCAMPER: Games for Imagination Development. However, the term SCAMPER was used by Eberle (1996: i) to "describe the mental activity the games are intended to bring about. Each of the seven letters of the word phrases making up the check list used to create the SCAMPER games", (p.i). However, the majority of researchers define SCAMPER as an acronym for seven techniques or activities; (S) substitute, (C) combine, (A) adapt, (M) modify, (P) put to another use, $(\mathrm{E})$ eliminate and $(\mathrm{R})$ revise (Çelikler and Harmer, 2015; Özyaprak, 2016; Khawaldeh \& Ali, 2016; Fahmy, Qoura and Hassan, 2017). In addition, SCAMPER is viewed by users differently; a strategy, a technique, a method, a model and a tool. In this study, it is used as a teaching model for developing the EFL student' essay writing skills via the use of the seven activities mentioned earlier.

\section{Methodology}

For testing the effectiveness of using the SACMPER Model in developing the EFL learners' essay writing skills, one experimental group-sample was selected among the third year students, Arish Faculty of Education during the first semester of the school year 2018-2019. Seven training sessions were applied at $3^{\text {rd }}$ year English Department students at Arish Faculty of Education. The ages of students ranged from 20 -21 years old. 
The experiment took 4 weeks, two sessions weekly, each session lasting 3 hours. Students were exposed to the SCAMPER (Substitute, Combine, Adapt, Modify, Put to other use, Eliminate, Reverse) Model in their essay writing. Each session focused on one of SCAMPER seven activities. The introductory and assessing sessions took 4 hours; two hours each.

\section{Research Design}

\section{Participants}

All the participants were assigned to one experimental group. The population of this study was 97 EFL students (54 females \&43males) enrolled in the third year English Department, Faculty of Education, Arish University during the first semester of the school year 2018-2019. Although all students attended the training program, 33 (21 females and 12 males) of the participants were excluded from the statistical analysis because they participated in the pilot study that aimed at verifying the reliability of the attitudes questionnaire. The average of the participants' ages ranged from 20 to 21 years old.

\section{Instruments}

The instruments below were developed by the researcher and used in the present study:

Based on the literature review and the activities of SCAMPER Model in terms of essay writing namely; substitute, combine, adapt, modify, practice, eliminate and revise. However, the instruments below were developed by the researcher and used in the present study:

The Essay Writing Scoring Rubric

The researcher reviewed some of the previous researches related to the use of rubrics as scoring tools for the scoring of students' written work i.e., the rubric developed, validated and used by the Arab Open University which is 
an affiliation of the British Open University and the rubric developed and validated by Al-saydalani, (2016). Out of these rubrics, the researcher developed a rubric that covered the six targeted essay writing skills namely; ideas, organization, vocabulary choice, structure, mechanics and editing. The rubric was used in scoring participants' essays in the pre and posttests.

1. The Attitude Measurement towards Using ACAMPER Model for Developing EFL Learners' Essay Writing Skills This measurement was devised by the researcher to measure EFL students' attitudes towards the use of SCAMPER Model for enhancing their essay writing skills. This rating scale of 1 to 5 was designed based on the examination of relevant literature (see e.g.Alma'shy,2011;Nazara, 2011; Usaha and Yaikhong, 2012;Juraid, 2016 and Al-Houti \& Aldaihani, 2018). The measurement was split into two main sections:

a. The demographic Information section which covered three items; names gender and age.

b. The Statements section which consisted of 24 items with a five-point Likert-type scales ranging from 5 to 1 . They are: 'Strongly Agree' (5), 'Agree' (4), 'Neutral' (3), 'Disagree' (2) and 'Strongly Disagree.'(1)

\section{Validity \& Reliability of the Measurement}

To check its validity, the measurement was submitted to 7 specialist-jury members in TEFL to examine and approve the measurement items. According to the jury members' comments, the researcher made the necessary modifications to the measurement in order to be ready for the pilot study application.

To verify its reliability, clarity and ease, the measurement was piloted to a 33 EFL third year-randomly selected studentsample. The reliability coefficient of the measurement items was computed using three methods of Cronbach's alpha coefficient (0.89), the Guttman Split- Half method (0.874) and Spearmen- 
Brown method (0.886) which all indicate that the measurement is highly reliable. The EFL participants in the pilot study were excluded from the statistical analysis and the revised version of the attitude measurement was administered.

3. The Pre and Post Essay writing Test

Participants were asked to write an essay consisting of at least five paragraphs on "Education". The same written test was applied to the participants (pre \& post) to measure the impact of the training program using the SCAMPER Model for enhancing their essay writing skills.

\section{Administration}

Pre-test:

All participants were given two hours to sit for the pretest. They were invited to write their essays about "Education".

\section{Attitudes Measurement}

Right after the participants finished writing their essays (pre-test), they were asked to respond to the attitudes measurement.

After the administration of the pre-test and the attitudes measurement, all participants attended an introductory briefing session ( 2 hours) about the use of SCAMPER Model in essay writing. A handout showing the meaning of each of the seven letters which represents the seven activities of SCAMPER was distributed to all students. Examples were provided to students for the use of more clarifications of the concepts of activities in producing a good quality of essay writing. In addition, students were encouraged to clarify about unclear concepts related to the use of SCAMPER in essay writing. When all the concepts were clear to the students' minds, the intervention took place.

\section{Procedures}

The SCAMPER Model in Essay Writing 
The SCAMPER model, however, is easy to apply in essay writing. When the EFL learners tend to start writing an essay, they begin with a brainstorming activity that enables them to generate the ideas needed for this particular activity in order to produce a better quality of an essay. They might rethink of producing or developing a better essay format in the future. However, there is a set of questions related to each one of the seven SCAMPER activities. These questions direct students' thoughts towards accomplishing the essay writing properly.

\section{Substitute:}

The substitute activity tends to provide an alternative word, sentence, idea, expression or tense to produce the essay in a better quality. In order to write a well written academic essay, it should be clearly stated about: what would the students substitute? Are there any words, sentences, ideas, expressions, tenses or formats that can be swapped? What part of the essay writing process can be replaced with a better alternative? Would this substitute work better somewhere else in the essay being written? What would happen if one part is substituted by another part? Will this substitute lead to a better quality of the essay?

\section{Combine:}

The "combine" activity tends to join two or more ideas, sentences or paragraphs together in order to produce a better, coherent written essay.

In order to write a well written academic essay, what can be combined? Is there a blend of ideas, suggestions, expressions, formats that might work? What can students add in from each other? Will certain ideas, suggestions or ideas fit together in their essay writing?

Adapt: 
The "adapt" activity tends to put the students in a brainstorming discussion that enables them to think of generating innovative ideas that help them improve the essay in hand.

In order to write a well written academic essay, what can the target group of writers adapt? Can they adapt certain ideas, styles, sentences, expressions, wisdoms or sayings to produce a well written piece of writing?

\section{Modify}

The "modify" activity, tends to provide the students with the ability to unleash better adjustments to their essays.

In order to write a well written academic essay, what can essay writers do in order to make their essays longer or shorter? How will adjusting the writing process improve the final product of essay writing? Are there any ideas, expressions or suggestions that can be added in order to affect the length of the essay being written? Are there long sentences/paragraphs that need to be shortened or vice versa?

Put to another Use:

This activity is concerned with structuring the essay in hand to a better style or format.

In order to write a well written academic essay, what part of the essay in hand can be used elsewhere in the body of the same essay? Is there a way for students to put their writings differently? Can students' writings be put in another format in order to be developed differently? Are there certain expressions that can be moved to another paragraph/place in the essay in order to better affect it?

\section{Eliminate:}


The "eliminate" activity helps students to find out needless parts of their essays and remove them in order to make their final product a better piece of writing.

In order to write a well written academic essay, is there anything that students can eliminate? Are there certain sentences that can be eliminated? Are there any complicated writing styles that can be simplified? Can anything be removed from the students' essays in order to make them easier to understand? What would happen if a certain part of the essay is removed?

\section{Rearrange:}

This final activity "rearrange/reflect" refers to students' reflection on how they use this model in essay writing.

In order to write a well written academic essay, is there any way that can be done in order to reverse, rearrange, rewrite, and reproduce the students' essays in a better format? How will essay writers reflect on how they use this model in their essay writing? (See Figure 1 for the seven activities of the SCAMPER Model). 


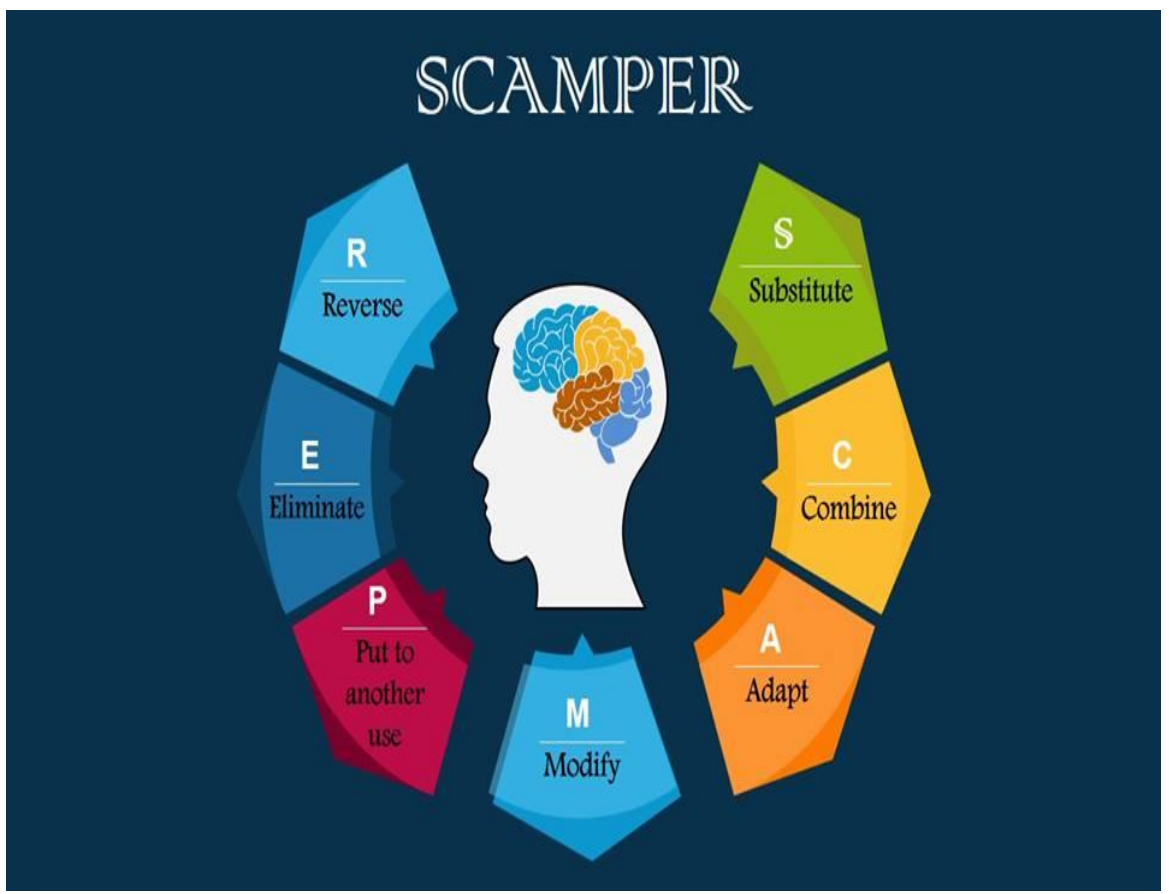

Figure 1: Shows the seven activities of the SCAMPER Model.

Training the Participants on the Use of SCAMPER in Essay Writing

The procedures followed in the administration of the SCAMPER Model in enhancing EFL learners' essay writing skills were as follows:

1. The teaching sessions were held twice a week; Mondays and Wednesdays. Each training session took three hours. The main objective of the training sessions was to acquaint students with the use of SCAMPER Model in essay writing.

2. Students were given 15 minutes to work on each paragraph of their essays. Paragraphs were shared by all participants and collective feedback was made by all under the supervision of the instructor (An assistant lecturer of TEFL at Arish Faculty of Education). 
3. The feedback focused on students' essay writings according to the six activities namely; ideas, organization, word choice, structure, mechanics and editing.

4. The points of strength and weakness, excellent expressions and common errors were highlighted so that students make use of positive and negative remarks on their writings.

5. After a detailed feedback session the students who scored less than 6 out of 10 were directed to redo their paragraphs in the light of the feedback.

6. The length of each teaching session was 3 hours including a 10-mintue break in the middle of each training session.

7. The training on essay writing took 7-three-hour sessions in addition to the pre and posttests and the briefing session.

8. All students worked on one topic in each training sessions. The topics of the training sessions were Sports, Technology, The Internet, Marriage, University Life and Tourism in North Sinai.

9. A WhatsApp group was created to help participants share ideas and feedback related to the SCAMPER activities.

\section{Posttest \& Attitude Measurement}

After all training sessions had concluded, all participants sat for the post essay writing skill test. They were given two hours to complete the post test. They were asked to write their essay on 'Education,' which was also the topic of the pretest. Each participant wrote their essay independently.

After completing the essays, students were given a 10-minute break before moving on to fill out the 24-item attitude measurement which took them an hour to complete.

Statistical Analysis

The Results of the Application of the Essay Writing Skills Test 
1. In order to test hypothesis 1: "There are statistically significant differences at the 0.05 level between the pretesting and post testing of the experimental group in terms of enhancing essay writing skills of EFL learners in favor of the post testing", the tvalue was calculated to indicate the significant differences between the mean scores of the study sample in the pre and post applications to test the essay writing skills using the SPSS program. The results are shown in the table below.

Table 1:-Results of t-test for the scores of the study sample in the pre and post-applications of the Essay writing skills test.

\begin{tabular}{|c|c|c|c|c|c|c|}
\hline Skills & App. & N. & Mean & $\begin{array}{l}\text { Std. } \\
\text { Dev }\end{array}$ & $\begin{array}{c}\mathrm{t}- \\
\text { value }\end{array}$ & P. \\
\hline \multirow{2}{*}{ Ideas } & Pre & \multirow{2}{*}{64} & 5.71 & 0.63 & \multirow{2}{*}{26.785} & \multirow{2}{*}{0.01} \\
\hline & Post & & 8.27 & 0.54 & & \\
\hline \multirow{2}{*}{ Organization } & Pre & \multirow{2}{*}{64} & 5.68 & 1.35 & \multirow{2}{*}{17.644} & \multirow{2}{*}{0.01} \\
\hline & Post & & 8.87 & 0.34 & & \\
\hline \multirow{2}{*}{$\begin{array}{c}\text { Word } \\
\text { Choice }\end{array}$} & Pre & \multirow{2}{*}{64} & 5.56 & 1.01 & \multirow{2}{*}{20.439} & \multirow{2}{*}{0.01} \\
\hline & Post & & 8.62 & 0.61 & & \\
\hline \multirow{2}{*}{ Structure } & Pre & \multirow{2}{*}{64} & 5.54 & 0.78 & \multirow{2}{*}{24.619} & \multirow{2}{*}{0.01} \\
\hline & Post & & 8.54 & 0.59 & & \\
\hline \multirow{2}{*}{ Mechanics } & Pre & \multirow{2}{*}{64} & 5.44 & 0.82 & \multirow{2}{*}{24.205} & \multirow{2}{*}{0.01} \\
\hline & Post & & 8.44 & 0.62 & & \\
\hline \multirow{2}{*}{ Editing } & Pre & \multirow{2}{*}{64} & 5.56 & 0.82 & \multirow{2}{*}{23.872} & \multirow{2}{*}{0.01} \\
\hline & Post & & 8.33 & 0.54 & & \\
\hline \multirow{2}{*}{ Total } & Pre & \multirow{2}{*}{64} & 33.49 & 4.49 & \multirow{2}{*}{27.624} & \multirow{2}{*}{0.01} \\
\hline & Post & & 51.08 & 2.46 & & \\
\hline
\end{tabular}

*Significant at 0.001 level 
The table above indicates that all t-values are significant at the 0.01 level, and the degree of freedom (62). This indicates that there are significant differences between the pre and post administration in the essay writing skills test. This means that there are significant differences at $(\alpha \leq 0.01)$ level between the mean scores of the study sample in the pre and post applications of essay writing skills test, in favor of the post-application.

The frequencies of the study sample responses to the measurement items and significance of differences between goodness of fit were calculated via the application of Chi-square $(\chi 2)$ for goodness of fit. The statistical analysis of frequencies was made using SPSS and hence, the results are shown the table below.

Table 2 Shows the results of Chi-square test $(\chi 2)$ for goodness of fit to calculate the significance of the differences between the frequencies of the respondents' answers to the measurement items.

\begin{tabular}{|c|c|c|c|c|c|c|c|c|}
\hline$\stackrel{0}{Z}$ & 营 & 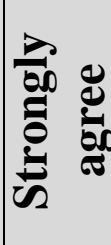 & 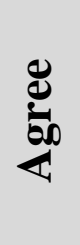 & 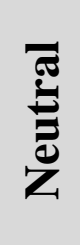 & 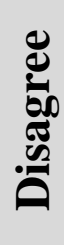 & 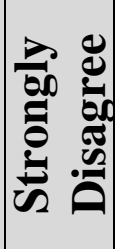 & อี & 氜 \\
\hline 1 & $\begin{array}{l}\text { Encourages me to } \\
\text { collaborate with } \\
\text { colleagues when to } \\
\text { plan for writing. }\end{array}$ & 28 & 34 & 2 & 0 & 0 & 64 & 87.88 \\
\hline 2 & $\begin{array}{l}\text { Improves my } \\
\text { writing accuracy. }\end{array}$ & 51 & 13 & 0 & 0 & 0 & 64 & 152.41 \\
\hline 3 & $\begin{array}{l}\text { Enhances my } \\
\text { thinking } \\
\text { brainstorming. }\end{array}$ & 39 & 25 & 6 & 0 & 0 & 64 & 103.66 \\
\hline 4 & $\begin{array}{l}\text { increases my word } \\
\text { choice. }\end{array}$ & 28 & 23 & 12 & 1 & 0 & 64 & 49.91 \\
\hline
\end{tabular}




\begin{tabular}{|c|c|c|c|c|c|c|c|c|}
\hline$\stackrel{\ominus}{Z}$ & 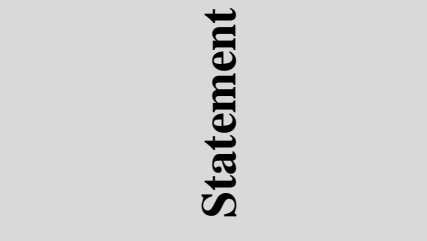 & 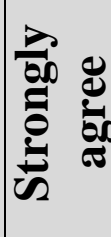 & 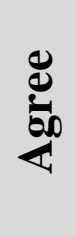 & 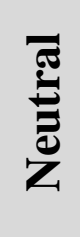 & 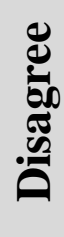 & 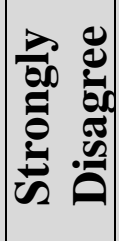 & $\stackrel{\bar{t}}{\stackrel{5}{\theta}}$ & 已 \\
\hline 5 & $\begin{array}{l}\text { Makes writing tasks } \\
\text { easier. }\end{array}$ & 28 & 24 & 12 & 0 & 0 & 64 & 53.50 \\
\hline 6 & $\begin{array}{l}\text { Makes essay writing } \\
\text { more interesting and } \\
\text { enjoyable. }\end{array}$ & 25 & 22 & 16 & 1 & 0 & 64 & 42.72 \\
\hline 7 & $\begin{array}{l}\text { Promotes } \\
\text { cooperative } \\
\text { activities during } \\
\text { writing sessions. }\end{array}$ & 20 & 21 & 19 & 4 & 0 & 64 & 31.16 \\
\hline 8 & $\begin{array}{l}\text { Increases my } \\
\text { interests by offering } \\
\text { suggestions/ideas. }\end{array}$ & 27 & 24 & 10 & 3 & 0 & 64 & 46.47 \\
\hline 9 & $\begin{array}{l}\text { Leads to reducing } \\
\text { my writing errors. }\end{array}$ & 35 & 28 & 1 & 0 & 0 & 64 & 93.03 \\
\hline 10 & $\begin{array}{l}\text { Enhances my } \\
\text { motivation to write } \\
\text { an essay. }\end{array}$ & 23 & 25 & 14 & 2 & 0 & 64 & 41.78 \\
\hline 11 & $\begin{array}{l}\text { Allows more } \\
\text { opportunities to } \\
\text { share about essay } \\
\text { writing. }\end{array}$ & 30 & 24 & 9 & 1 & 0 & 64 & 57.72 \\
\hline 12 & $\begin{array}{l}\text { Develops my } \\
\text { interpersonal skills. }\end{array}$ & 32 & 27 & 5 & 0 & 0 & 64 & 74.91 \\
\hline 13 & $\begin{array}{l}\text { Makes me attentive } \\
\text { and enthusiastic all } \\
\text { the time. }\end{array}$ & 14 & 28 & 18 & 4 & 0 & 64 & 39.13 \\
\hline 14 & $\begin{array}{l}\text { Creates an } \\
\text { interesting } \\
\text { classroom } \\
\text { environment. }\end{array}$ & 27 & 25 & 12 & 0 & 0 & 64 & 53.03 \\
\hline
\end{tabular}




\begin{tabular}{|c|c|c|c|c|c|c|c|c|}
\hline$\stackrel{\circ}{Z}$ & 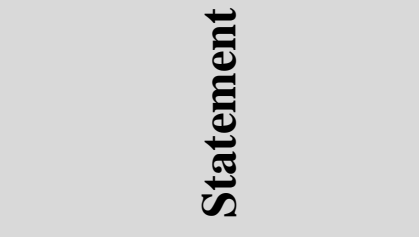 & 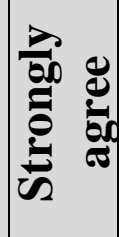 & 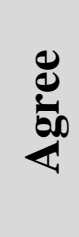 & 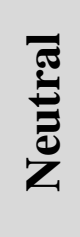 & 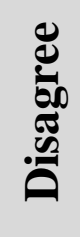 & 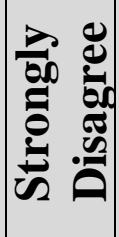 & $\stackrel{\vec{\sigma}}{\stackrel{\tilde{\sigma}}{\theta}}$ & 司 \\
\hline 15 & $\begin{array}{l}\text { Enhances my } \\
\text { sentence structure. }\end{array}$ & 41 & 18 & 4 & 1 & 0 & 64 & 93.97 \\
\hline 16 & $\begin{array}{l}\text { is a matter of } \\
\text { wasting time. }\end{array}$ & 0 & 0 & 4 & 16 & 44 & 64 & 108.50 \\
\hline 17 & $\begin{array}{l}\text { helps me focus on } \\
\text { topic all the time. }\end{array}$ & 25 & 24 & 12 & 3 & 0 & 64 & 41.78 \\
\hline 18 & $\begin{array}{l}\text { is difficult to use in } \\
\text { essay writing. }\end{array}$ & 0 & 5 & 14 & 29 & 16 & 64 & 38.97 \\
\hline 19 & $\begin{array}{l}\text { helps in generating } \\
\text { ideas. }\end{array}$ & 35 & 24 & 5 & 0 & 0 & 64 & 78.66 \\
\hline 20 & $\begin{array}{l}\text { leads to a better use } \\
\text { of mechanics } \\
\text { (spelling, } \\
\text { punctuations, } \\
\text { grammar, } \\
\text { capitalization). }\end{array}$ & 35 & 20 & 8 & 1 & 0 & 64 & 68.03 \\
\hline 21 & $\begin{array}{l}\text { helps me produce } \\
\text { well-organized } \\
\text { essay; beginning, } \\
\text { middle \& end. }\end{array}$ & 37 & 24 & 3 & 0 & 0 & 64 & 88.66 \\
\hline 22 & $\begin{array}{l}\text { is good to be used in } \\
\text { other content areas. }\end{array}$ & 16 & 26 & 20 & 1 & 1 & 64 & 40.22 \\
\hline 23 & $\begin{array}{l}\text { helps me increase } \\
\text { my vocabulary. }\end{array}$ & 29 & 27 & 8 & 0 & 0 & 64 & 63.66 \\
\hline 24 & $\begin{array}{l}\text { leads to developing } \\
\text { the written } \\
\text { expressions. }\end{array}$ & 32 & 25 & 7 & 0 & 0 & 64 & 68.66 \\
\hline
\end{tabular}

The above table indicates that all the values of chisquared $\chi 2$ are statistically significant at the 0.01 level and hence, 
the differences in the responses are real and significant and this is shown in the classifications below:

- $70.83 \%$ of the responses to the measurement items in which the value of the chi-square $\chi 2$ was statistically significant at the 0.01 level were in favor of the "Strongly Agree" response.

- $20.83 \%$ of responses to the measurement items in which the value chi-square $\chi 2$ was statistically significant at the 0.01 level were in favor of "Agree" response.

- $4.17 \%$ of the responses to the measurement items where the value of the chi-square $\chi 2$ was statistically significant at the 0.01 level were in favor of the "Strongly Disagree" response.

- $4.17 \%$ of the responses to the measurement items in which the value of the chi-square $\chi 2$ was statistically significant at the 0.01 level were in favor of the "Disagree "response.

The Result of the Application of the Essay Writing Skills Test

Table 3: The effect size of SCAMPER Model on developing the study sample's essay writing skills

\begin{tabular}{|c|c|c|c|c|c|}
\hline Skills & Test & DF & t-value & $\begin{array}{c}\text { Test } \\
\text { Value }\end{array}$ & $\begin{array}{c}\text { Effect } \\
\text { Size }\end{array}$ \\
\hline \multirow{2}{*}{ Ideas } & $d$ & \multirow{2}{*}{62} & \multirow{2}{*}{26.785} & 4.32 & Large \\
\hline & $\left(\eta^{2}\right)$ & & & 0.92 & Large \\
\hline \multirow{2}{*}{ Organization } & $d$ & \multirow{2}{*}{62} & \multirow{2}{*}{17.644} & 2.94 & Large \\
\hline & $\left(\eta^{2}\right)$ & & & 0.83 & Large \\
\hline \multirow{2}{*}{ Word Choice } & $d$ & \multirow{2}{*}{62} & \multirow{2}{*}{20.439} & 3.61 & Large \\
\hline & $\left(\eta^{2}\right)$ & & & 0.87 & Large \\
\hline \multirow{2}{*}{ Structure } & $d$ & \multirow{2}{*}{62} & \multirow{2}{*}{24.619} & 4.34 & Large \\
\hline & $\left(\eta^{2}\right)$ & & & 0.91 & Large \\
\hline \multirow{2}{*}{ Mechanics } & $d$ & \multirow{2}{*}{62} & \multirow{2}{*}{24.205} & 4.13 & Large \\
\hline & $\left(\eta^{2}\right)$ & & & 0.90 & Large \\
\hline
\end{tabular}




\begin{tabular}{|c|c|c|c|c|c|}
\hline \multirow{2}{*}{ Skills } & Test & \multirow{2}{*}{ DF } & t-value & $\begin{array}{c}\text { Test } \\
\text { Value }\end{array}$ & $\begin{array}{c}\text { Effect } \\
\text { Size }\end{array}$ \\
\hline \multirow{2}{*}{ Editing } & $\boldsymbol{d}$ & \multirow{2}{*}{62} & \multirow{2}{*}{23.872} & 3.99 & Large \\
\cline { 2 - 4 } & $\left(\boldsymbol{\eta}^{\mathbf{2}}\right)$ & & 0.90 & Large \\
\hline \multirow{2}{*}{ Total } & $\boldsymbol{d}$ & \multirow{2}{*}{62} & \multirow{2}{*}{27.624} & 4.85 & Large \\
\cline { 2 - 4 } & $\left(\boldsymbol{\eta}^{\mathbf{2}}\right)$ & & 0.93 & Large \\
\hline
\end{tabular}

The table above shows the large calculated effect size of using the SCAMPER Model on developing the study sample's essay writing skills. This large effect size is attributed to the well use of the SCAMPER Model as a teaching strategy for developing the EFL learners' essay writing skills.

Hypothesis 2: There are statistically significant differences at the 0 . 05 level between the pre administration and post administration of the experimental group in terms of enhancing essay writing skills of EFL learners in favor of the post administration.

In order to examine the second hypothesis, the paired- samples ttest was computed between the means of scores of the participants in the attitudes measurement towards the use of SCAMPER Model for enhancing EFL learners' essay writing skills in both pretest and posttest. The procedure was executed by SPSS program. The results are presented below:

Table 4: the results of t-test of participants' scores in the attitudes measurement towards the use of SCAMPER Model for enhancing their essay writing skills in both the pretest and posttest.

\begin{tabular}{|c|c|c|c|c|c|c|c|}
\hline Group & N & Mean & $\begin{array}{c}\text { Std. } \\
\text { Deviation }\end{array}$ & df & $\begin{array}{c}\text { t- } \\
\text { value }\end{array}$ & Sig. & Result \\
\hline Pre & \multirow{2}{*}{64} & 70.88 & 5.11 & 63 & 29.18 & 0.01 & $\begin{array}{c}\text { Significant } \\
\text { at the 0.01 } \\
\text { level (2- } \\
\text { tailed) }\end{array}$ \\
\cline { 1 - 5 } & & 100.39 & 6.46 & & & & \\
\hline
\end{tabular}


As shown in the table above, there are statistically significant difference at the 0.01 level (2-tailed) and degree of freedom at (63). This indicates that there are real differences between the levels of the participants in the attitudes measurement towards the use of the SCAMPER Model for enhancing their essay writing skills in both the pretest and posttest and hence, the hypothesis is supported. This means that there are statistically significant between the means of scores of the study participants in the attitudes measurement towards the use of SCAMPER Model in enhancing essay writing skills in both the pre-test and the post-test in favor of the post administration.

\section{Conclusions and Recommendations}

This study provides empirical evidence on how to use SCAMPER Model to enhance EFL learners' essay writing skills. Table (3) shows a statistically significant difference between the experimental group students' scores in the pre and post administration of the essay writing skills test in favor of the post testing. This shows the effectiveness of using the SCAMPER Model in enhancing the EFL learners' essay writing skills. This result might be due to the good characteristics of the SCAMPER Model in terms of dealing with different activities of essay writing namely; substitute, combine, adapt etc.,. In addition, the results of this study are similar to the results of Al-Thanyan's study (2015) in terms of generating ideas in essay writing skills of university students, Horn's study (2016) in terms of exploring relationships, and searching for new and different combinations. In addition, this study is similar to Serrat's study (2009), Moreno et al., (2014), Abdallah's study (2015) and Horn's study in terms of encouraging students to think of new ideas, combine existing ideas in new ideas and generate original ideas. Furthermore, this study is similar to Donovan ideas (2017) in terms of providing students with characteristics of good writing such as clarity, focus, organization, word choice, mechanics of writing; spelling, capitalization, grammar style of writing. 
Table (4) which is related to the EFL learners' attitudes towards using the SCAMPER Model in enhancing their essay writing skills, it is clear that there is a statistical significant difference in favor of the post administration. This shows EFL learners' positive attitudes towards using the SCAMPER Model in enhancing their essay writing skills. This positive attitude might be a result of the different SCAMPER related activities of substitute, combine, adapt, modify, practice, eliminate and rearrange. Each one of these activities stimulated EFL learners' thinking skills, brainstorming, creative writing skills, exploring relationships and generating ideas, producing original ideas and enhancing creativity. These positive results agree with the results of Moreno et al., (2014), Harman \& Celikler, (2015), Ozyaprak (2016) and Horn 2016).

Suggestions for Further Research

1. Using the SCAMPER Model for developing other aspects of language teaching and learning, such as listening, speaking, reading, reading comprehension etc.,.

2. Designing a program for training in-service EFL teachers to use the SCAMPER Model in various aspects of TEFL. 


\section{References}

Abdessalam, S. (2016). The role of Feedback in Developing EFL

Students' Writing Skills. The Case of Students from

Department of English at Mohamed V University, Rabat. Omni Scriptum GmbH \& Co.KG.

Abdul-Qader, A. \& Ismail, A. (2015). The Effectiveness of SCAMPER Model in Developing the Creative Linguistic Performance of Linguistically Gifted Pupils at the Preparatory Developing The Creative Linguistic Performance of Linguistically Stage. The International Journal for Educational Research. The United Arab Emirates University (37), 257-294.

Abdallah, M.S.M. (2015). Writing II for 2nd Year EFLStudent Teachers.First edition. College of Education, Assiut University. https://eric. ed.gov/? $q=$ essay+writing + skills \&id=ED557724.Retrieved on November 30 ${ }^{\text {th }}, 2018$.

Ablahad, F., \& Fataah, N. (2003). The effect of SCAMBER program on developing creative thinking. Research Journal of Teachers College, 13(1), 35-61.

Abu-seif, A. M. \& Magableh, N. M. (2016). The Effect of Using SCAMPER Strategy on Improving Jordanian Female tenth Grade Students' Creative Writing Skills.IUG Journal of Educational and Psychology Sciences, Vol.25, No 3, 2017, pp 289-309.

Ahmed, A. M. A. H. (2011). The EFL Essay Writing Difficulties of Egyptian Student Teachers of English: Implications for Essay Writing Curric-ulum and Instruction. An Unpublished Ph.D. Dissertation, Graduate School of Education, University of Exeter. England, United Kingdom. 
Ahmed, A. H. (2010). Students' problems with cohesion and coherence in EFL essay writing in Egypt: Different Perspectives. Literacy Information and Computer Education Journal (LICEJ), 1(4), 211-221.https://doi.org/10. 20533/licej.2040.2589.2010.0030.

Al Badarin, S. (2006). Effectiveness of a Strategy-based Program for Idea-Generating (SCAMPER) on the Creative and Self Concept of Jordanian Sample of Students with Learning Disabilities.Unpublished Doctoral Dissertation.The Jordanian University, Amman, Jordan.

Alex, O. F. (1953). Applied Imagination: Principle and Procedures of Creative Thinking. New York, Scribner.

Al Harthy, S.D.S (2015). The Impact of Using SCAMPER Program on Developing English Language Vocabularies among First Grade Middle School Students in Makkah Al Mukarramah. Unpublished Master Thesis, Faculty of Education, Um Al Qura University, KSA. Al-Houti, S. K. \& Aldaihani, S. M. (2018).Letting the Cat out of the Bag: EFL College Students' Attitudes towards Learning English Idioms. International Journal of Higher Education. Vol. 7, No. 1; 2018.

Al-Jarrah, T. M., Mansor, N., Rahid, R.A., Bashir, I., AlJarrah, M. (2018).EFL Students' Attitudes Toward Using Metacognition Strategies in Writing English Language Teaching .English Language Teaching Journal; Vol. 11, 2018.pp.162-171.

Al-ma'shy, A. (2011). Causes of EFL Speaking Weakness in Saudi Secondary Schools in Al-Gunfuthah City.

Unpublished Doctoral Dissertation, College of Arts, King Saud University, Riadh, KSA.

Alrowethy, M. (2012).The Effect of SCAMPER Program on

Creative Thinking among Gifted and Talented Students. 
Un Published M.A thesis, Faculty of Education, Taibah University, KSA.

Al-Roomy, M. (2016). Developing Students' EFL Writing Skills by Enhancing their Oral interactions. International Journal of Applied Linguistics \& English Literature. Vol. 5, No. (5). Pp.24-31.

Besant, H. (2016). The Journey of Brainstorming. Journal of Transformational Innovation, Vol. 2, (1), Summer 2016, Pp.1-7. Regent University, School of Business \& Leadership.

Buser, K., Buser, J., Gladding, T., \& Wilkerson, J. (2011). The creative counselor: using the SCAMPER model in counselor training. Journal of Creativity in Mental Health, 6(4), 256-273.

Çelikler, D. \&Harman, G. (2015).The Effect of the SCAMPER Technique in Raising Awareness Regarding the Collection and Utilization of Solid Waste. Journal of Education and Practice. Vol.6, No.10, 2015, pp. $149-159$.

Chang, K. (2012). Theoretical Perspectives of Scamper Strategy on an International Practice in Continuing Professional Development for English Teachers. English Teaching, 67 (1), 45-48.

Chulvi, V., González-Cruz, M. C., Mulet, E., \& AguilarZambrano, J. (2013). Influence of the type of ideageneration method on the creativity of solutions. Research in Engineering Design, 24(1), 33-41.

Coffin, C., Curry, M., Goodman, S., Hewings, A., Lillis, T., \& Swann, J. (2003). Teaching academic writing : a toolkit for higher education. London \& New York: Routledge. 
4. Colby, R. (2014). The SCAMPER Method: A Creativity Crisis Breaker. https:// writingishardwork. com/2014/08 /21/the-scamper-method-a-creativity-crisis-breaker/.

Davis, B. (2015). How to Brainstorm when Writing an Essay. https://blog. Inte- rnational student. com/2015/05/howto-brainstorm-when-writing-an-essay/

Doly, S. (2013).The Characteristics of Good Government Writing. https:// web. uvic.ca/ $\sim$ sdoyle/E302/Notes/Characteristics.html.

Donovan, M. (2017).Eight Characteristics of Good Writing.https://www. writing forward.com/betterwriting/characteristics-of-good-writing.

Eberele, B. (1996). SCAMPER: Creative Games and Activities for Imaginations Development. Let your imagination run wild! Prufrock Press Inc. USA.

Elmansy, R. (2018). A Guide to the SCAMPER Technique for Creative Thinking. http://www.designorate.com/a-guideto-the-scamper technique - for-creative-thinking/

El-Zraigat, A. (2012). Counseling gifted and talented in Jordanian inclusive

schools: Conclusion and implication. International Journal of Special

Education, 27 (2), 57-63.

Fahmy, G. A., Qoura, A. A., \& Hassan, S.R. (2017). Using SCAMPER-based Activities in Teaching Story to Enhance EFL Primary Stage Pupils' Speaking Skills. Journal of research in Curriculum, Instruction and Educational Technology. Vol. 3, No. 4. Oct.2017. Pp. 11-33.

Faraj, A. K. A. (2015). Scaffolding EFL Students' Writing through the Writing Process Approach. Journal of Education and Practice. Vol.6, No, 13. Pp. 131-141. 
Haridy, M. M. S. (2017). The Statistical Effectiveness: Concept and Measurement Haridy's Simple \& Timed Gain Ratios (H-SGR \&H-TGR). Journal of Arab Study in Education \& Psychology (ASEP), Issue (82), Feb.2017.Pp. 369379.

Harman, D. Celikler. G. (2015). The Effect of the SCAMPER Technique in Raising Awareness Regarding the Collection and Utilization of Solid Waste.Journal of Education and Practice, 6(10), 149-159.

Horn, C. (2016).Creative Brainstorming with SCAMPER.https://www.fcps. edu/ blog/creativebrainstorming-scamper.

Idek, M. (2016). Measuring the Application of SCAMPER Technique in Facilitating Creative and Critical Thinking in Composing Short Stories and Poems.Malaysian Journal of Higher Order Thinking Skills in Education. Edition 2/2016.Pp. 31- 53.

Irvin, L. L. (2010).What is "Academic"Writing? https://wac.colostate.edu/books /writingspaces1/Irvin-what-is-academic-writing.pdf

Islim, O. F. \&Karatas, S. (2016). Using the SCAMPER Technique in ICT Course to Enhance Creative Problem Solving Skills: An Experimental Study.Turkish Online Journal of Educational Technology (JOJET).

December 2016. Pp. 1290-1296.

Khawaldeh, H. M. \& Ali, R. M. (2016). The Effect of SCAMPER Program on Creative Thinking among Gifted and Talented Students. International Journal of Sciences: Basic and Applied Research (IJSBAR). Volume 30, $\quad$ No 2, pp 4858. 
Koura, A. A., \& Zahran, F. A. (2017). Using Habits of Mind to Develop EFL Writing Skills and Autonomy. Arab English Journal, Vol. 8, No. (4). Pp. 183-198. DOI: http://dx. Doi.org/10.24093/awej/vo18no4.12.

Loveless,B.(2018). The Basics of Effective Essay Writing. https://www .educat-ioncorner.com/writing-an-essay.html

Majid, A., Tan, G., \&Soh, C. (2003). Enhancing children's creativity: An exploratory study on using the internet and SCAMPER as creative writing Tools. Korean Journal of Thinking and Problem Solving, 13(2), 67-82.

Moreno, D. P., Yang, M., C., Hernández, A. A., Wood, K.L. (2014). Creativity in Transactional Design Problems: NonIntuitive Findings of an Expert Study Using SCAMPER. International Design Conference, Design 2014, Dubrovnik Croatia, May 19 - 22, 2014.

Mulder, P. (2018). SCAMPER Technique by Bob Eberle. https://www. Toolsh-ero. com/ creativity/scampertechnique-bob-eberle/.

Muschla, G. R. (2011). Practice Makes Perfect Mastering Writing (Practice Makes Perfect Series. ${ }^{\text {st }}$ Edition. McGraw Hill, New York. USA.

Nazara, T. (2011).Students' Perceptions on EFL Speaking Skill Development. Journal of English Teaching, 1 (1), 28-42. Okasha, M. A., \& Hamdi, S. A. (2014). Using strategic writing techniques for promoting EFL writing skills and attitudes. Journal of Language Teaching \& Research, 5(3), 1114.https://doi.org/10.4304/jltr.5.3. 674-681. Retrieved on November $30^{\text {th }}$, 2018.

Ozyaprak, M. (2016). The effectiveness of SCAMPER technique on creative thinking skills.Journal for the Education of 
Gifted Young Scientists, 4(1), 31-40. DOI:http: //dx.doi.org/10.17478/JEGYS.2016116348

Poon, J. C. Y, Au, A. C. Y, \& Sin Lau, T. M. Y. (2014). The feasibility of enhancement of knowledge and selfconfidence in creativity: A pilot study of a threehour SCAMPER workshop on secondary students.

Teaching Skills and creativity, 14, 32-40.https://www. Science direct. com/sciencel

article/pii/S1871187114000431\#!Retrieved on

December $1^{\text {st }}, 2018$.

Richards, J. C. \&Lassonde, C. A. (2011). Strategies for all

Primary Students: Scaffolding Independent Mini-Lessons. John Wiley \& Sons, Ivc. San Francisco, CA, USA.

Ryan, G. (2017). 10 Important Essay Writing Skills You Need to Know. https: $\quad / / w w w . k i b i n . c o m / e s s a y-w r i t i n g-$ blog/important-essay-writing- skills/.Retrieved on December 1, 2018.

5. Sawalha, M. \& Abu Jarad, M. (2017).The Effectiveness of SCAMPER Program on Developing Creative Writing among Ninth Grade Students in Jordan. Hebron University Research Journal (HURJ). Volume 12, Issue 1, 2017, pp.( $221-225$ )

Şenel, E. (2018). The Integration of Creative Writing into Academic Writing Skills in EFL Classes. International Journal of Languages' Education and Teaching Volume 6, Issue 2, June 2018, p. 115-120.

Serrat, O. (2009). The SCAMPER Technique. Asian Development Bank. https://www.adb.org/publications/scamper-technique.Retrieved on November $11^{\text {th }}, 2018$. 
Toraman, S., \&Altun, S. (2013). Application of the Six Thinking Hats and SCAMPER techniques on the 7 th grade course unit" human and environment": An exemplary case study. Mevlana International Journal of Education, 3(4), 166185.

Usaha, S., \&Yaikhong, K. (2012). A measure of EFL public speaking class anxiety: Scale development and preliminary validation and reliability. English Language Teaching,5(12), 23-34. Doi.org/10.5539/elt.v5n12p23.

Yagci, E. (2012). A study on Parents' Opinions on directed brainstorming

Sciences, (43), 485-494.

Zaiyadi, Z. A., Abdullah, E., Muhamad, S.H., \& Mustapha, G. (2015). Creative Thinking in Academic Essay Writing. $1^{\text {st }}$ Global Conference on Technology in Language Learning, 2015 (GLIT2015). 